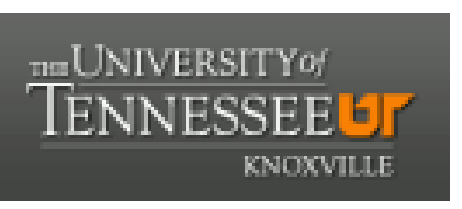

University of Tennessee, Knoxville

TRACE: Tennessee Research and Creative

Exchange

September 2011

\title{
Judges, Lawyers, and a Predictive Theory of Legal Complexity
}

Benjamin H. Barton

The University of Tennessee College of Law, bbarton@utk.edu

Follow this and additional works at: https://trace.tennessee.edu/utk_lawpubl

Part of the Law Commons

\section{Recommended Citation}

Barton, Benjamin H., "Judges, Lawyers, and a Predictive Theory of Legal Complexity" (2011). College of Law Faculty Scholarship.

https://trace.tennessee.edu/utk_lawpubl/38

This is brought to you for free and open access by the Law at TRACE: Tennessee Research and Creative Exchange. It has been accepted for inclusion in College of Law Faculty Scholarship by an authorized administrator of TRACE:

Tennessee Research and Creative Exchange. For more information, please contact trace@utk.edu. 


\title{
Judges, Lawyers, and a Predictive Theory of Legal Complexity
}

\author{
Benjamin H. Barton ${ }^{1}$
}

This Article uses public choice theory and the new institutionalism to discuss the incentives, proclivities, and shared backgrounds of lawyers and judges. In America every law-making judge has a single unifying characteristic; each is a former lawyer. This shared background has powerful and unexplored effects on the shape and structure of American law. This Article argues that the common interests, thought-processes, training, and incentives of Judges and lawyers lead inexorably to greater complexity in judge-made law. These same factors lead to the following prediction: judge-created law will be most complex in areas where a) elite lawyers regularly practice; b) judges may have a personal preference in the case that can be written-around by way of legal complexity; and c) the subject area interests the judge, or is generally considered prestigious. The Article uses the law of standing as a case study.

This is the Court of Chancery, which has its decaying houses and its blighted lands in every shire, which has its worn out lunatic in every madhouse and its dead in every churchyard, which has its ruined suitor with his slipshod heels and threadbare dress borrowing and begging through the round of every man's acquaintance, which gives to monied might the means abundantly of wearing out the right, which so exhausts finances, patience, courage, hope, so overthrows the brain and breaks the heart, that there is not an honorable man among its practitioners who would not give - who does not often give the warning, 'Suffer any wrong that can be done you rather than come here!'

\section{-- Charles Dickens, Bleak House}

The broadest judicial bias I see . . . is the bias in favor of legal complexity. The volumes of the third edition of the Federal Reporter spread themselves like Kudzu vine over the shelves of law libraries.

\footnotetext{
1 Associate Professor of Law, University of Tennessee College of Law. B.A. 1991, Haverford College; J.D. 1996, University of Michigan. The author gives special thanks to Indya Kincannon, Glenn Reynolds, Jeff Hirsch, Alex Long, and the Honorable Diana Gribbon Motz.
} 
-- The Honorable Dennis Jacobs, Chief Judge United States Court of Appeals for the Second Circuit

The multiplication of rules and standards, carrying in its train as it does endless debate over boundaries, is one of the banes of the American legal system, a source of its appalling complexity.

-- Holmes v. Buss, 506 F. 3d 576 (7th Cir. 2007, Posner, J.)

In recent years political scientists, economists and law professors have begun exploring two separate areas of inquiry: legal complexity and judicial behavior. This Article combines these topics and uses public choice theory and an institutional analysis of legal thought to offer a predictive theory of judge-made legal complexity. My theory thus does not address the entire topic of legal complexity - authors like Peter Schuck ${ }^{2}$ and Richard Epstein ${ }^{3}$ have focused on complexity within the entire legal system, including legislators, bureaucrats, and the judiciary. Instead, I focus on a very specific type of legal complexity: the type created by judges with the help of lawyers. In particular I focus on what I call indeterminate complexity, by which I mean complexity which adds to, rather than clarifies, indeterminacy. ${ }^{4}$

I use public choice theory and the "new institutionalism" to discuss the incentives, proclivities, and shared backgrounds of lawyers and judges. In America every lawmaking judge has a single unifying characteristic, regardless of their political affiliation, judicial philosophy, race, gender, or religion. Every American judge is a former lawyer. ${ }^{5}$ This shared background has powerful and unexplored effects on the shape and structure of American law. This Article argues that the common characteristics, thought-

\footnotetext{
${ }^{2}$ Peter H. Schuck, Legal Complexity: Some Causes, Consequences, and Cures, 42 DUKE L.J. 1 (1992).

${ }^{3}$ RICHARD A. EPSTEIN, SimPle RULES FOR A COMPLEX WORLD (Harvard University Press 1995).

${ }^{4}$ As I will discuss below, not all complexity fits this description. Some complexity adds granularity and particularity to the law, reducing indeterminacy.

${ }^{5}$ There are some magistrate level judgeships filled by non-lawyers. See DoRIS M. ProvinE, JUDGING CREDENTIALS: NONLAWYER JUdGES AND THE POLITICS OF PROFESSIONALISM (1986).
} 
processes, training, and incentives of Judges and lawyers lead inexorably to greater complexity in judge-made law.

Complexity benefits lawyers by raising the demand for and difficulty of legal services, but more importantly, the crafting and creating of complex legal arguments are what many lawyers most enjoy about the practice. This is especially so for the lawyers who enjoyed and succeeded in law school. These same lawyers then become law-making judges and continue to enjoy complexity as the very heart of the legal process. Law making judges also gain the benefits of creating complexity (the actual opinion crafting) while trial courts bear the main costs (the application of complexity). The only cost to the appellate courts is facing later cases under the complex law, but for the reasons noted above for appellate judges complexity is not a bug; it's a feature. There is an old adage that hard cases make bad law. A corollary is that interesting cases make unnecessarily complex law. This is especially so if complexity can allow a judge to hide a policy preference within a thicket of complexity.

These factors and more lead to the following prediction: judge-created law will be most complex in areas where a) elite lawyers regularly practice; b) judges may have a personal preference in the case that can be written-around by way of legal complexity; and c) the subject area interests the judge, or is generally considered prestigious. In the interests of brevity I choose a single area of law - standing - as my case study, but there are many alternative examples. ${ }^{6}$

\footnotetext{
${ }^{6}$ Much of Federal Constitutional law fits the theory. Consider the recent shift in Second Amendment jurisprudence. For most of the last century the Second Amendment has been a relative jurisprudential backwater with simple rules and few precedents. Over the last twenty years or so there has been a great deal of new interest among academics, judges and high-level lawyers in the Second Amendment, with the decision in District of Columbia v. Heller, 554 U.S. _ (2008) announcing a new, and infinitely more complex, reading of Second Amendment law.
} 
The Article proceeds as follows. Part I places this work in context with my earlier treatments of lawyers and judges. Part II defines the legal complexity at issue and canvasses some of the previous work in the area. Part III describes the institutional characteristics and internal incentives of both the legal profession and the law-making judiciary: who they are, their career and educational experiences, what they do, and what incentives drive their behavior. Part III then uses this institutional analysis to state why both lawyers and law-making judges tend to favor complexity. Part IV offers the law of standing as a case study in judge-made complexity.

\section{THE LAWYER-JUDGE HYPOTHESIS}

In recent years I have spent a great deal of time applying the tools of public choice theory and the new institutionalism to American judges and lawyers. In America almost all judges are formerly lawyers, and the central insight of my work has been that this has powerful, and in some cases insalubrious effects on the shape of American law.

In my first foray into this area I limited myself to the regulation of the legal profession itself. In America the regulation of lawyers is exclusively controlled by State Supreme Courts. As a general rule State Supreme Courts claim this power as a result of separation of powers doctrine and their "inherent authority" over the practice of law. The exercise of this authority has wide-ranging consequences: both the rules of entry and rules of professional conduct for the legal profession are controlled in the final instance

Another example is the federal law of employment discrimination. State law and precedents have dealt with wrongful discharge cases for years, and offer a relatively simple procedural and substantive framework. By comparison federal employment discrimination law has grown more and more arcane over the years, with a multistep procedure for presenting the proof and tangled substantive law. See Alex B. Long, "If the Train Should Jump the Track . . ".: Divergent Interpretations of State and Federal Employment Discrimination Statutes, 40 GA. L. REV. 469 (2006). 
by lawyers themselves. Since virtually every other profession is governed by state legislatures, this is a substantial regulatory advantage for lawyers. ${ }^{7}$

Consistent with the dictates of public choice theory, this advantage has played out to the benefit of the legal profession as a whole and to the detriment of the public.

Collective action problems, agency capture, and rent-seeking are even more pronounced in lawyer regulation than in other areas, because of the confluence of interests between judges and lawyers, and the lack of public knowledge or power to address the situation. ${ }^{8}$

More recently I have stretched the theory beyond the results in regulation to case specific areas where judges have clearly favored the interests of the legal profession over the public. My lawyer-judge hypothesis posited that whenever a legal issue impinges upon the interests of the legal profession as a whole judges tend to choose the result that benefits lawyers. Some of the cases I analyzed are a result of judges looking out for their own, but more often the cases result from a judge's innate sympathy and empathy for the alleged plight of lawyers.

So, for example, the lawyer client relationship is powerfully protected in legal proceedings by the lawyer-client privilege, the oldest and strongest of the evidentiary privileges. By comparison the doctor-patient or priest-penitent privileges are much weaker. Similarly, legal malpractice claims are among the hardest types of torts to win. In most legal malpractice cases a plaintiff must prove a "case within a case" to satisfy the element of causation. Thus, the plaintiff must establish not only negligence; she must

\footnotetext{
${ }^{7}$ Benjamin H. Barton, Why Do We Regulate Lawyers? An Economic Analysis of the Justifications for Entry and Conduct Regulation, 33 ARIZ. ST. L.J. 429 (2001); Benjamin H. Barton, An Institutional Analysis of Lawyer Regulation: Who Should Control Lawyer Regulation-Courts, Legislatures, or the Market?, 37 GA. L. REV. 1167 (2003).

${ }^{8}$ Benjamin H. Barton, An Institutional Analysis of Lawyer Regulation: Who Should Control Lawyer Regulation- Courts, Legislatures, or the Market?, 37 GA. L. REV. 1167 (2003).
} 
also establish that "but for" the negligence she would have won (and collected on) the underlying case at trial. By contrast, in many states a patient can recover against a doctor for a "lost chance" of survival regardless of whether the doctor's error was the "but for" cause of death. ${ }^{9}$

In this Article I add another, broader layer to my argument that the tight connection between lawyers and judges has significant and costly real world consequences. This Article argues that the unique relationship and similarity of backgrounds, skills, and incentives of lawyers and judges leads them to work together to increase legal complexity.

\section{LEGAL COMPLEXITY}

Before launching into the argument it is necessary to first define legal complexity and then briefly describe some of its costs and benefits. We start with definitions.

\section{A. Defining Legal Complexity}

Ironically, past legal definitions of complexity have themselves tended towards convolution. For example, Peter Schuck describes legal complexity across four axes density, complexity, institutional differentiation, and indeterminacy. ${ }^{10}$ Deborah Paul uses three criteria - complication, intractability, and incoherence. ${ }^{11}$ Richard Epstein offers a definition that defines complexity in terms of the public and private costs of compliance with any rule. ${ }^{12}$

\footnotetext{
${ }^{9}$ Benjamin H. Barton, Do Judges Systematically Favor the Interests of the Legal Profession?, 59 ALA. L. REV. 453 (2008).

${ }^{10}$ Schuck, supra note 2, at 4 .

${ }^{11}$ Deborah L. Paul, The Sources of Tax Complexity: How Much Simplicity Can Fundamental Tax Reform Achieve?, 76 N.C. L. REV. 151, 157-62 (1997).

${ }^{12}$ Epstein, supra note 3, at 25-26.
} 
By comparison, consider Louis Kaplow's relatively straightforward statement that "the relative complexity of legal rules refers to the number and difficulty of distinctions the rules make." ${ }^{13}$ This simpler definition will work fine for our purposes.

It is also important to clarify exactly the type of complexity at issue. First, I am only discussing judge-made law, so I make no effort to discuss complexity that results from legislative, executive, bureaucratic actions. Except for the actions of lawyers and clients in court, I am also ignoring complexity that arises from private ordering.

In particular this Article focuses on what I call the law-making courts, in comparison to law-applying courts. The classic law-making courts are the U.S. and State Supreme Courts. ${ }^{14}$ To a lesser extent the various Federal and State Courts of Appeal also regularly make law. ${ }^{15}$ District courts at the Federal and state level are considered lawapplying courts. This is not to say that these courts do not have substantial (and in some cases largely unfettered) discretion to make law in any given case, or that these courts do not add to the overall complexity of the system. Instead, it is the nature of precedent, and the likelihood that a written, published decision by a court will affect existing or create new law that separates the law-making from the law-applying courts. ${ }^{16}$

\footnotetext{
${ }^{13}$ Louis Kaplow, A Model of the Optimal Complexity of Legal Rules, 11 J.L. ECON. \& ORG. 150, 150 (1995). This definition jibes nicely with non-legal definitions, like John Casti's definition that "the complexity of an object is directly proportional to the length of its shortest possible description." JOHN L. CASTI, COMPLEXIFICATION 9 (Harper Collins 1995) (1994).

${ }^{14}$ Posner has gone so far as to argue recently that the U.S. Supreme Court's caseload and approach makes the Court an essentially legislative body. Richard A. Posner, Foreword: A Political Court, 119 HARV. L. REV. 31 (2005).

${ }^{15}$ I say "to a lesser extent" not because these courts produce less law (they actually produce much more), but because they are not courts of last resort, so they tend to create less far-reaching law.

${ }^{16}$ Separating these courts, and their various institutional backgrounds, incentives and proclivities is one of the key additions this Article offers, as many previous studies of legal complexity have focused on the interests and actions of the judiciary as a whole, instead of considering the great differences between each level of the judiciary, and Supreme Courts' greater capacity for adding complexity and while bearing little of the costs for any such addition.
} 
Second, I am trying to isolate what I call indeterminate complexity. I add the modifier "indeterminate" because in some areas of the law complexity may be appropriate and helpful. While legal complexity often has negative connotations, economists and others have noted that complexity carries both strengths and weaknesses. ${ }^{17}$ Complexity can allow the law to be more closely tailored to very specific cases, and if the area of law is one where it is critical to have very precise calibration, complexity is often necessary, even if not necessarily efficient.

If it's helpful, think of two separate continuums for judge-created law. One continuum considers whether the law is relatively simple or complex. The second considers whether the law is relatively determinate or indeterminate. As Schuck has noted, these types of calculations are not black and white. ${ }^{18}$ Any area of the law will fall somewhere on these continuums.

Moreover, being at an extreme of one continuum does not necessarily determine placement on the other. For example, simple rules can be determinate or indeterminate. Our courts could operate based on a single statement: "all disputes will be decided fairly." This statement is exceedingly simple, but would be woefully indeterminate in practice. By comparison, rules stating the legal age for drinking or voting are simple and determinate.

Similarly, complex systems can be determinate or indeterminate. Many IRS and EPA regulations are attempts to use complexity to increase determinacy. ${ }^{19}$ As described below, the law of standing is complex and indeterminate.

\footnotetext{
${ }^{17}$ Kaplow, supra note 12 , at $151-52$.

${ }^{18}$ Schuck, supra note 2, at 3-6.

19 The relative failure of this effort, however, may be evidence that it is harder than one might think to increase determinacy with complexity. Consider Edward McCaffery's discussion of indeterminacy,
} 
For our purposes indeterminate complexity occurs when complexity adds to,

rather than clarifies, indeterminacy. While complexity and indeterminacy often coincide, complex systems are not necessarily indeterminate. Complexity will sometimes add granularity and certainty. In this regard it is when indeterminacy and complexity run together that we should be most concerned: such a system has the many disadvantages of complexity, without any concomitant benefit of certainty or specificity.

The complexity literature offers general accord on three points. American law is often too complex, it is growing more complex over time, and this complexity growth is on balance harmful. ${ }^{20}$ I think it is clearly true that insofar as the law drifts towards indeterminate complexity, that drift is harmful. ${ }^{21}$ The most obvious expense is in transaction costs. When the law is complicated individuals need to hire lawyers to help decode it. When the law is complicated and indeterminate consumers receive the worst of all worlds - the expense of seeking legal advice without any clear answer about how to taxpayer behavior, and "dynamic complexity" in the creation of IRS regulations. Edward J. McCaffery, The Holy Grail of Tax Simplification, 1990 WIS. L. REV. 1267 (1990).

20 See, e.g., Epstein, supra note 3; Anthony D'Amato, Legal Uncertainty, 71 CAL. L. REV. 1 (1983); J.B. Ruhl, Complexity Theory as a Paradigm for the Dynamical Law-and-Society System: A Wake-Up Call for Legal Reductionism and the Modern Administrative State, 45 DUKE L.J. 849 (1996). To the empirically minded these citations will look a little thin. The empirical work on legal complexity has been relatively limited. Michael Heise has an interesting study of the perception of complexity by judges, lawyers, and juries in criminal cases. Michael Heise, Criminal Case Complexity: An Empirical Perspective, $1 \mathrm{~J}$.

EMPIRICAL LEGAl STUD. 331 (2004). There has also been some empirical work on complexity in contract drafting. Karen Eggleston et al., The Design and Interpretation of Contracts: Why Complexity Matters, 95 Nw. U. L. REV. 91 (2000). Peter Harris has published a study of citation rates in Supreme Court cases he termed complex, and the study was replicated in New Zealand's courts by Russell Smyth. Peter Harris, Difficult Cases and the Display of Authority, 1 J.L. ECON. \& ORG. 209 (1985); Russell Smythe, Case Complexity and Citation to Judicial Authority-Some Empirical Evidence from the New Zealand Court of Appeal, 10 E LAW- Murdoch U. EleCTRONIC J.L. 1 (2003), available at http://www.murdoch.edu.au/elaw/issues/v10n1/smyth101.html. None of these studies, however, demonstrate relative or growing complexity. Danièle Bourcier and Pierre Mazzega are planning an international measure of comparative complexity, but it appears to be in the design stage at present. See Daniele Bourcier \& Pierre Mazzega, Toward Measures of Complexity in Legal Systems, in INTERNATIONAL CONFERENCE ON ARTIFICIAL INTELLIGENCE AND LAW, PROCEEDINGS OF THE 11 TH INTERNATIONAL CONFERENCE ON ARTIFICIAL INTELLIGENCE AND LAW 211-215 (2007).

21 See, e.g., Gillian Hadfield, The Price of Law: How the Market for Lawyers Distorts the Justice System, 98 MICH. L. REV. 101 (2000). As with anything else, legal complexity has its defenders. R. George Wright, The Illusion of Simplicity: An Explanation of Why the Law Can't Just be Less Complex, 27 FLA. ST. U. L. REV. 715 (2000). 
proceed. This may explain why so many entrepreneurs plow forward without legal advice for as long as possible. Rather than pay for expensive advice that offers few actual answers it's better to act now and hope for the best. ${ }^{22}$

I am also persuaded that American law grows more complex over time. I am not, however, arguing that we are facing a "complexity crisis," or that law is more complicated than ever before. To the contrary, while the term "legal complexity" is of a relatively recent vintage, recognition of the underlying phenomena is hardly new. ${ }^{23}$

Charles Dickens' Bleak House offers a particularly compelling portrait of a legal system out of control, buried beneath layers upon layers of complexity. ${ }^{24}$ The indeterminacy of law has been a persistent thread of the legal realist movement, ${ }^{25}$ and later the critical legal studies movement. ${ }^{26}$

\section{B. Previous Studies of Indeterminacy and Legal Complexity}

I discuss both indeterminacy and complexity below because my theory addresses situations where they overlap. Studies of complexity and indeterminacy naturally implicate economic and other analytical descriptions of the creation of law. Richard Posner and William Landes have argued that legal precedent is similar to capital stock. The capital stock of precedents depreciates over time, creating uncertainty. This

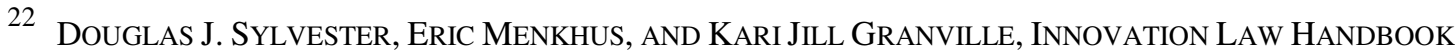
(ASU Ctr. for the Study of Law, Sci. \& Tech. 2005), available at http://ssrn.com/abstract=999451.

${ }^{23}$ For reasons of brevity and relevance I am not canvassing the interesting recent work utilizing complexity, evolutionary and chaos theories to describe legal change, because they tend to describe systems of change, and not growth in complexity. See, e.g., Donald T. Hornstein, Complexity Theory, Adaptation, and Administrative Law, 54 DUKE L.J. 913 (2005); J.B. Ruhl, Complexity Theory as a Paradigm for the Dynamical Law-and-Society System: A Wake-Up Call for Legal Reductionism and the Modern Administrative State, 45 DUKE L.J. 849 (1996). Nor am I discussing the recent empirical work on complexity in private law transactions. Eggleston, supra note 19.

${ }^{24}$ CHARLES DiCKenS, BleaK House (Random House 1980) (1853).

${ }^{25}$ Joseph William Singer, Legal Realism Now, 76 CAL. L. REV. 465, 470 (1988).

${ }^{26}$ See, e.g., Ken Kress, Legal Indeterminacy, 77 CAL. L. REV. 283 (1989); Brian Leiter, Legal Indeterminacy, 1 LEGAL THEORY 481 (1995).
} 
uncertainty leads to additional litigation that replenishes the capital stock and decreases uncertainty, and the cycle begins again. $^{27}$

This theory has been subject to two criticisms that are useful to the analysis here. The first is to question whether more litigation does, in fact, lead to precedents that decrease uncertainty, or whether it just adds additional layers of complexity and uncertainty. ${ }^{28}$ The second is whether Landes and Posner ignore the interests and activities of a key third party: lawyers. Paul Rubin and Martin Bailey have argued that the uncertainty and complexity of products liability law is a direct result of the interests of the lawyers who litigate those cases. ${ }^{29}$

Anthony D'Amato's Legal Uncertainty was one of the first attempts to explicitly connect the incentives of the players in the legal system to ever-increasing indeterminacy. He concluded that "Legal certainty decreases over time. Rules and principles of law become more and more uncertain in content and in application because legal systems are biased in favor of unravelling those rules and principles." 30

D'Amato noted that potential litigants had an incentive to change their behavior in response to law to try to find "gray areas," where law's application was unclear. He argued that judges "desire status, fame, and greatness in their profession. Routinely following precedent and always acting predictably do not often lead to notice and

\footnotetext{
${ }^{27}$ William M. Landes \& Richard A. Posner, Legal Precedent: A Theoretical and Empirical Analysis, 19 J.L. \& ECON. 249 (1976).

${ }^{28}$ There is a split on this question. For example, Gennaioli and Shleifer assume that new precedents naturally increase the precision of legal rules. Nicola Gennaioli, The Evolution of Common Law, $115 \mathrm{~J}$. POL. ECON. 43 (2007). By comparison, Hadfield argues that there is a natural entropy to legal complexity. Hadfield, supra note 20. See also Gillian Hadfield, Bias in the Evolution of Legal Rules, 80 Geo. L.J. 583 (1992).

${ }^{29}$ Paul H. Rubin and Martin J. Bailey, The Role of Lawyers in Changing the Law, 23 J. LEGAL STUD. 807 (1994). Lynn LoPucki has also added substantially to the literature considering the role of lawyers in law creation. See Lynn M. LoPucki, Legal Culture, Legal Strategy, and the Law in Lawyers' Heads, 90 Nw. U. L. REV. 1498 (1996); Lynn M. LoPucki \& Walter O. Weyrauch, A Theory of Legal Strategy, 49 DuKE L.J. 1405 (2000).

${ }^{30}$ D'Amato, supra note 19, at 1 .
} 
acclaim." Likewise, the incentives of lawyers and litigants favor uncertainty: "The mathematical theory of gambler's risk, recently elaborated into 'prospect theory,' suggests that a person disadvantaged by the application of a legal rule has a greater incentive to avoid the rule than the person advantaged by it has to affirm its application." In sum, D'Amato argued that the legal system as a whole has a structural bias in favor of uncertainty and complexity.

Peter Schuck followed up on these insights with his own study of legal complexity. He similarly argued that legal complexity is growing and deleterious. He expanded upon D'Amato's analysis of institutional incentives by focusing on the benefits of complexity for legislators and their staffs, bureaucrats, litigants, lawyers and judges. Each of these players has reason to favor complex and/or indeterminate rules. Complex rules allow much more freedom to each player in the system and less accountability, because it is costly for the public to decipher or lobby against complex systems. ${ }^{31}$

Schuck does not use the language of public choice, but it should be clear that complexity is an important tool in the arsenal of self-interested government officials, whether legislators, bureaucrats or judges. Complexity allows each of these officials to pursue their individual goals under cover of an opaque legal system that the public cannot disentangle. If an aggrieved member of the public wishes to change an area of the law she must first decipher it, and then try to understand exactly which government actor or actors are responsible for the situation at hand, and then lobby for change. ${ }^{32}$

\footnotetext{
${ }^{31}$ Schuck, supra note 2 , at 27-35.

32 In my previous work on judicial control of the regulation of lawyers I noted the substantial obstacles between the public and lobbying for a change in lawyer regulation. The first such barrier would be determining exactly who to contact, since State Supreme Courts control the regulation, not the legislature.
} 
Schuck adds a second valuable insight - the craft value of complexity. All of the players in the legal system enjoy looking smart and building what they see as elegant and complex solutions to problems. Nevertheless, Schuck does not focus on why the craft value of complexity would be especially hard to resist for law-making judges, a subject I cover below. $^{33}$

\section{WHY LAWYERS AND LAW-MAKING JUDGES FAVOR COMPLEXITY}

This Part argues that lawyers and judges both have strong incentives to increase legal complexity. I separate these reasons into two categories, crass and subtle. Public choice theory helps illuminate the crass considerations and the new institutionalism explains the subtle. I may be too kind to my colleagues, but I tend to think the subtle explanations actually better explain the complexity dynamic than the crass.

\section{A. The Crass}

Public choice theory is the application of economic analysis to non-economic behavior. When applied to government decision-making each governmental actor is independently rational and seeks to maximize personal utility. Thus, the easiest way to understand a governmental action is to consider the underlying institutional and individual incentives involved. Public Choice theory has also been used to show how narrow interest groups triumph in the political realm over more diffuse public interests. Interest groups are able to deliver the things that legislators desire: campaign

\footnotetext{
33 One humorous aside about both D'Amato and Schuck's treatment of complexity is the large role they ascribe to legal scholarship in the trend towards complexity. D'Amato, supra note 19, at 21-22; Schuck, supra note 2, at 34-38. More recently Robert Spitzer has blamed law reviews for faulty constitutional interpretation. See Robert J. SPitZer, SAVIng the Constitution From Lawyers (2008). As I argue below, I do think that law professors and law schools are among the causes of legal complexity. But in light of the current trend of judges and practicing lawyers largely ignoring legal scholarship it seems particularly solipsistic to claim that a professorial taste for complexity in scholarship has done anything more than decrease readership. Harry T. Edwards, The Growing Disjunction Between Legal Education and the Legal Profession, 91 MicH. L. REV. 34 (1992).
} 
contributions, votes, and assistance through lobbying. By delivering these items interestgroups can "purchase" self-interested regulations or laws.

Because courts are less open to lobbying than legislatures some public choice theorists have assumed that judicial decision-making is less affected by interest group pressures. ${ }^{34}$ Nevertheless, a review of judicial behavior towards the legal profession well establishes that judges are hardly immune from external pressures on their decisionmaking, especially when those pressures come from the legal profession. ${ }^{35}$

As such, I usually find it useful in predicting judicial behavior to begin with the incentives of the legal profession. Lawyers have multiple reasons to favor complexity. First and foremost, across the legal profession lawyers are selling a single good technical expertise of the legal system. The more complicated that system is (and that includes procedural and substantive complexity) the more business there will be for lawyers. $^{36}$

If the system were to grow simpler, usage of lawyers would tumble, and that is true regardless of the subject area involved. Consider the push towards non-lawyered mediation (whether electronic systems such as Ebay's or in-person mediation) as a less expensive and simpler system of dispute resolution. Litigants have moved towards these less formal dispute resolution mechanisms to avoid the expense and complexity of traditional court proceedings. ${ }^{37}$

\footnotetext{
${ }^{34}$ See Frank B. Cross, The Judiciary and Public Choice, 50 HASTINGS L.J. 355, 358-60 (1999) (providing an exhaustive list of those public choice theorists who believe judicial decision-making is less affected by interest group pressures).

${ }^{35}$ Barton, supra note 6; Barton, supra note 8; LYNN M. LOPUCKI, COURTING FAILURE: How COMPETITION FOR BIG CASES IS CORRUPTING THE BANKRUPTCY COURTS (University of Michigan Press 2005).

${ }^{36}$ Hadfield is particularly persuasive on this point. See Hadfield, supra note 24; Hadfield, supra note 20.

37 The Ebay online dispute resolution system is particularly on point. Because of issues of personal service and jurisdiction it is very complicated for a citizen in one state to sue a citizen in another state, especially if that state is far away, and the amount at issue is relatively small. The Ebay system moots all of that
} 
Seen in this light complexity is a classic result of Public Choice theory. Lawyers are a well organized interest group that pushes for beneficial law (in this case complicated law and procedure) at the expense of the public at large. Public debates over legal complexity bear this out: whenever non-lawyers complain about the legal system, lawyers fall back to claims of unique institutional knowledge. "Of course the legal system is complicated. If you were a lawyer you would understand why it must be so." ${ }^{38}$ It's also worth noting how lawyers add legal value to litigation. Lawyers add value by finding applicable precedents and law, and then either distinguishing or applying them through a process of case law synthesis. Regardless of whether precedents are to be distinguished or embraced, overall complexity assists. Having multiple overlapping precedents or multi-factor tests always allows a lawyer room to find good precedent and distinguish bad precedent. This is especially so because a lawyer can almost always distinguish her case on the facts. In this regard lawyers build snowflakes: they are trying to make each case unique and sui generis.

Gillian Hadfield has likewise argued that the American lawyer's dedication to zealous advocacy on behalf of individual clients virtually guarantees an effort to build complexity, and ignore the broader benefits of simplicity. ${ }^{39}$ If a more complex solution will suit a lawyer's client that is the rule the lawyer will suggest, regardless of the overall

complexity in favor of simple, effective and cheap online mediation. See Colin Rule, OnLine Dispute RESOlUTION FOR BUSINESS: B2B, ECOMMERCE, CONSUMER, EMPLOYMENT, INSURANCE, AND OTHER COMMERCIAL CONFLICTS (Jossey-Bass 2002).

${ }^{38}$ This is true even in relatively simple and straightforward areas of the law like divorce and bankruptcy. At the low end most of this law and procedure is very simple, but most jurisdictions require lawyers to file the paperwork and prosecute the cases, even when a lay advocate or paralegal could certainly serve adequately.

39 Hadfield, supra note 24. See Brian Z. TAmanaha, LaW aS A MEANS to AN END (Cambridge University Press 2006) (offering a broader discussion of the corrosive effects of lawyer instrumentalism). 
effect on the law. The sum total of each of these individual case decisions in favor of complexity snowball across the system leading naturally to entropy.

Complexity is not, however, generally good for society as a whole, or legal clients specifically. Nevertheless, because of informational asymmetry and agency costs clients are not usually in a position to advocate for a simple result over more complexity in any given case, let alone across the law in general. ${ }^{40}$ Moreover, note the unique nature of the collective action problem. On the whole, complexity is a great detriment to the purchasers of legal services. But on an individual basis, complexity can be a client's best friend, especially if an able lawyer utilizes that complexity towards a better individual case result. $^{41}$ Thus it is not just that an individual incentive towards sloth overwhelms a group benefit: in legal complexity the individual choice in favor of complexity actually carries benefits to each individual client.

Complexity would not, however, seem like it would much benefit courts. Complex systems are harder to administer, so perhaps courts should serve as a natural barrier to complexity. As the growth in legal complexity shows, this has not proven to be the case. A study of judicial incentives and behavior helps explain why.

There are multiple reasons for judges to follow lawyers and favor complexity. The first is that the courts that are most affected by complexity - trial courts - are not the courts generally responsible for its creation. Law-making appellate courts are in charge

\footnotetext{
${ }^{40}$ A great example of this gap is the tort reform efforts. It's worth noting that as a general rule these reforms have focused on damages caps or jurisdictional controls, and not fundamental reform of the law. Damage caps and jurisdictional changes do limit the overall losses in litigation, but they do little to reign in indeterminacy or complexity, which remains untouched. In this way the defense lawyers are still quite necessary to defend these cases.

${ }^{41}$ This phenomenon is also reflected in surveys that show that the public has a generally unfavorable impression of the legal profession as a whole, but a favorable impression of any individual lawyers that worked for them. Steven K. Berenson, Institutional Professionalism for Lawyers: Realizing the Virtues of Civic Professionalism, 109 W. VA. L. REV. 67, 67-68 (2006).
} 
of creating precedential complexity, and complexity only affects them the next time that issue appears on appeal. These courts are not on the front line of deciphering or applying complexity. $^{42}$

Second, lawyers favor complexity consciously and unconsciously, and selfinterested judges will always work in accord with the desires of lawyers, because they are the repeat players in the system, and the judiciary's main customers and patrons. One of the critical lessons of game theory is that players in iterated games have a strong incentive to cooperate, ${ }^{43}$ while players in one time games like the classic prisoner's dilemma discourage cooperation. ${ }^{44}$ Consequently, lawyers and judges will naturally want to work together, judges and most litigants, not so much.

Moreover, the lawyers that eventually become judges have good reason to favor their former profession. Most judges remain members of bar associations and remain close professionally and personally with their former colleagues after joining the judiciary. $^{45}$

Moreover, between the ABA, State Bar Associations, and donations to the campaigns of elected judges, lawyers are easily the most influential group in the selection and retention of judges. Lawyers give the bulk of the campaign donations to elected judges. ${ }^{46}$ In elective states - including merit selection states with retention elections bar associations frequently endorse judicial candidates, and conduct and publish "bar polls" on the judges. Many justices were selected for their positions through "merit

\footnotetext{
42 (For a particularly evocative description of this effect by a Federal Judge, see Dennis Jacobs, The Secret Life of Judges, 75 FORDHAM L. REV. 2855 (2007).

43 See Robert Axelrod, The Evolution of CoOperation 68-69 (1984).

44 ERIC RASMUSEn, GAMES AND INFORMATION: AN INTRODUCTION TO GAME THEORY, 16-19 (1994).

45 Barton, supra note 6.

46 A recent rise in corporate contributions in state supreme court elections may have changed this balance, however. See Penny J. White, Preserving The Legacy: A Tribute To Chief Justice Harry L. Carrico, One Who Exalted Judicial Independence, 38 U. RICH. L.R. 615, 619-24 (2004).
} 
plans" that place substantial selection authority in state and local bar associations. Lastly, the ABA has always played a critical role in the selection of federal judges. ${ }^{47}$ With lawyers involved at every level of the process the likelihood that a judge will owe her position to lawyers is extraordinarily high.

Lynn LoPucki offers a breathtaking example of the influence of lawyers over judges in Courting Failure. ${ }^{48}$ At the behest of local bankruptcy attorneys, bankruptcy courts across the country are competing to attract the largest and most complicated bankruptcy cases. Note that the "winner" of this competition wins a great deal of new and complicated work. Nevertheless, pressure from local lawyers and a desire to do the work itself have resulted in blatant forum shopping and competitions among the judges on procedural and substantive law, all to the great benefit of the local bankruptcy bars that can attract the biggest (and most lucrative) bankruptcies. ${ }^{49}$

Third, just as complexity has benefits for the legal profession as a whole, it carries great benefits for the law-making judiciary as well. Complexity makes it easier to decide almost any case in line with the judge's other preferences. ${ }^{50}$ Scholars who advocate models of judicial behavior that focus upon non-legal explanations for judicial behavior, like the attitudinal model or critical race scholars, have thus often looked to complexity as the cover for true judicial motivations.

Fourth, while complexity does have costs, lawyers do a great deal of every judge's work. In the advocacy system most judges rely on the lawyers to do the bulk of the work in trying, briefing, researching, or investigating cases. When the system is

\footnotetext{
${ }^{47}$ Barton, supra note 6.

${ }^{48}$ LoPucki, supra note 31.

${ }^{49}$ Id.

${ }^{50}$ Eric J. Miller, Judicial Preference, 44 Hous. L. REV. 1275 (2008).
} 
working properly the judges sit back and decide cases based on the legal and factual work of the lawyers. ${ }^{51}$

On appeal the lawyers generally find and research the law, place it in written briefs, and then apply it to the facts at hand for the judges. As such, complexity arrives for the judge hand-wrapped by the litigants. Judges can, of course, disregard the lawyers' legal research or theories of the case. But insofar as that requires independent research or a novel legal outcome (and in many cases a simplification of the law would be novel) substantial additional work is required, and the judge risks the opprobrium of other judges or the legal profession. Thus, paradoxically, a judge seeking simplicity will have to work much harder than a judge who applies the complex theories and law presented by the lawyers in the case.

Fifth, while innovation in almost all areas of legal practice and judging has been painfully slow, ${ }^{52}$ one area of a judge's work - writing opinions - has been greatly streamlined by word processing technology. One hundred years ago it took substantial physical effort to write or edit a legal document. Even forty years ago judges worked through multiple drafts, hand-writing their changes in an effort to reach a final edit. Word processors have revolutionized this process, so a physical barrier to complexity (the hassle of committing it to paper) has been removed.

\footnotetext{
51 This aspect of the judicial incentive structure has led directly to higher barriers to entry - including requiring law school and a passing grade on the bar exam - because judges and current lawyers both profit when entry tightens. Lawyers profit from decreased competition and judges profit from better lawyers to work up their cases. Barton, supra note 6, at 1189-92.

52 Gillian Hadfield has recently argued that the regulation of lawyers itself has stifled legal innovation and costs consumers of legal services a great deal. Hadfield, supra note 20.
} 
Lastly, as noted below, law-making judges like complexity. It's likely that they were good at complexity as lawyers, and it is likely why they sought a job as a judge in the first place.

\section{B. The Subtle}

One of the key insights of the new institutionalism is that human behavior is bound by "institutions." The new institutionalism defines institutions broadly as "formal and informal rules that constrain individual behavior and shape human interaction.

[They] are the framework within which human interaction takes place."53 Institutions are thus a constellation of behaviors, rules, and norms that bind and constrain groups of individuals. By contrast, "organizations" are groups of people working together, like a company, the judiciary or a legislature. ${ }^{54}$

Legal thought itself is a powerful and constraining institution. In considering a judicial and lawyerly taste for complexity it is critical to understand how the institution of legal thought is developed and passed on within the legal profession and the judiciary. It is thus worth describing the career path of the law-making judge in America and how it leads inexorably to a taste for complexity.

The first stop is law school. Justice Frankfurter once opined that "the law is what the lawyers are. And the law and lawyers are what the law schools make them."55 The stated goal of American law school, to teach law students to "think like a lawyer," is a quite explicit attempt at institution creation. American law schools are aimed at the study

53 Douglas C. North, Institutions, Institutional Change And ECONOMic Performance 4 (1990); see also Thrainn Eggertsson, A Note on the Economics of Institutions, in EMPIRICAL STUDIES IN InStitutional ChANGE 6, 7 (Lee J. Alston, Thrainn Eggertsson, and Douglas C. North eds., 1996) ("formal and informal rules that constrain individual behavior and shape human interaction; institutional environment varies with a person's position in society.").

${ }^{54}$ NORTH, supra note _ at 5.

${ }^{55}$ Letter from Felix Frankfurter to Mr. Rosenwald (May 13, 1927) (on file with the Harvard Law School Library). 
(and celebration) of indeterminacy. In class and exams students are repeatedly presented with an unclear area of the law and asked to argue both sides of the issue. "Thinking like a lawyer" requires a student to see each issue as multi-faceted, and to recognize that the law likely does not have a clear answer for the questions raised in class or on the exams.

Students are instructed that for class and exams the important point is not to find the "right" answer, because there likely is no right answer. Instead, students are taught and graded on their thinking process: did they spot all of the potential issues? Once they spotted the issues, did they correctly analyze them, and note the different ways the law could apply? I have previously called this approach to teaching law "the siren song of indeterminacy." ${ }^{, 56}$ Law school's continual focus on gray areas is a specialized training in complexity, and the students who are best at it end up with the best grades and the highest credentials exiting law school.

Law schools are not, however, irrational to focus upon indeterminacy. The next stop for almost every law-making judge is practice. As noted above, coping with complexity and indeterminacy is much of what lawyers are paid to do.

The lawyers who are selected to be law-making (i.e. appellate) judges come from the elite of the profession. ${ }^{57}$ As members of this elite, these lawyers have mastered the skills involved in the creation and understanding of legal complexity. ${ }^{58}$ Furthermore, it is likely that they actually quite enjoy the entire process. When lawyers, judges, or law

\footnotetext{
${ }^{56}$ Benjamin H. Barton, The Emperor of Ocean Park: The Quintessence of Legal Academia, 92 CAL. L. REV. 585 (2004).

57 Jeffrey Stempel, A More Complete Look at Complexity, 40 ARIZ. L. REV. 781, 808 (1998). For example, graduates of elite law schools are disproportionately represented on the federal bench. Grutter v. Bollinger, 539 U.S. 306, 322 (2003).

${ }_{58}$ As support for this contention, consider that a study of federal appellate judges that found that most selfidentified "innovators" (those judges more comfortable with judicial lawmaking) had attended prestigious law schools, while most "interpreters" had not. J. WOODFORD HOWARD, COURTS OF APPEALS IN THE FEDERAl JUDICIAL SYSTEM 167-68 (1981).
} 
professors talk about a "true love of the law," they are talking about this exact process of digesting and generating complexity.

In addition to the sorting process of law school and practice, it is worth noting the power of self-selection for law-making judges. Many, if not most, of these judges have not taken their jobs for the money. Most earned or could earn more in private practice. It is likely that some chose the work for prestige, or job security (for judges appointed for life), or for a lighter workload, but there is another substantial non-economic benefit to becoming a law-making judge: the work itself.

American Judges who hear appeals have jobs that are radically dissimilar from the jobs of most lawyers or even district court judges. Law-making judges spend the vast majority of their time reading briefs, researching the law, and writing opinions. They hear oral arguments, but on a limited schedule and basis. They have very little contact with the public at large. As much as possible they delegate unpleasant or managerial tasks to staff and focus on the "fun" part of their job: legal reasoning and deciding cases. $^{59}$ Law-making judges thus spend almost all of their time engaged in the hermetic pursuit of legal complexity, a true "life of the law."

Every lawyer who becomes a judge knows what the job entails, and it is thus quite likely that they at least think they will enjoy it. A big part of the non-pecuniary benefit of the law-making judge is the pleasure (or "craft value" to use Schuck's terminology) that lawyers gain from legal complexity.

This helps explain why the "costs" of complexity don't deter law-making judges. To law-making judges complexity isn't a bug; it's a feature. If complexity means that

\footnotetext{
${ }^{59}$ Paul D. Carrington, A Critical Assessment of the Cultural and Institutional Roles of Appellate Courts, 9 J. APP. PRAC. \& PROCESS 231 (2007).
} 
later interesting appeals raising new and different legal questions in the same complex area will arise in the future, that is sauce for the goose.

It is also worth noting the ways that complexity fits the judicial interest in "prestige," which generally means how they are perceived among lawyers and other legal elites. ${ }^{60}$ Lawyers, legal academics, and other judges hold complex thinking and writing in high esteem. The more a judge is able to display a mastery of those skills the higher her concomitant prestige. This, in turn, raises the likelihood of judicial promotion, or other prestige-related benefits.

Paul Campos has also noted that an instinct as innocuous as the instinct to get each case right results in crippling complexity. "The emphasis on getting it right, and the agonized struggle to define just what that might entail, produce a distinctive vision of law that is totalizing, relentless, and most oblivious to such crass considerations as time, money, and possible limits to the powers of human reason." ${ }^{61}$ Richard Epstein likewise noted the problem of seeking "perfect justice" in individual cases. ${ }^{62}$

\section{The Prediction}

A combination of the crass and subtle leads to the following prediction: the law will be most complex in areas where a) elite lawyers regularly practice; b) judges may have a personal preference in the case that can be written-around by way of legal complexity; and c) the subject area interests the judge, or is generally considered prestigious. Areas staffed by elite lawyers tend towards complexity because elite lawyers tend to be the best at complex legal reasoning, and elite lawyers tend to have clients who

\footnotetext{
${ }^{60}$ Frederick Schauer, Incentives, Reputation, and the Inglorious Determinants of Judicial Behavior, $68 \mathrm{U}$. CIN. L. REV. 615, 627-31 (2000); Jacobs, supra note 38.

${ }^{61}$ PAUL CAMPOS, JURISMANIA 20 (1998).

${ }^{62}$ Epstein, supra note 3.
} 
can pay for additional complexity. If the area overlaps with an area of the law that the judge has a personal preference in, judges will bend towards complexity as a way to justify their decisions. Lastly, "prestigious" or interesting areas tend to exacerbate these other factors.

There are some obvious complex areas that fit these criteria, with constitutional law the clearest. Many lawyers became appellate judges specifically out of a desire to hear, think about, and decide complex constitutional cases. When those former lawyers get their chance to decide these cases reducing complexity is the last thing on their mind.

In sum, a brief review of the backgrounds, incentives, and proclivities of both lawyers and law-making judges establishes a strong, systemic bias towards complexity. I personally place more weight on the unconscious factors rather than a conscious bias, ${ }^{63}$ but regardless, the drift towards complexity is clear.

This is not to suggest that this drift is completely one-sided or that reform efforts are impossible. The reform of civil pleading requirements embodied by the current Federal Rules of Civil Procedure establishes that complexity (like any other interest group benefit gained by the logic of public choice and collective action theory) has boundaries, and that if the situation grows sufficiently grave it can be rolled back. ${ }^{64}$

\section{CASE STUDY - THE LAW OF STANDING}

\footnotetext{
63 This may show my own personal bias as well. The political scientists who have advocated the attitudinal model of judging (that judges decide their cases on the basis of political affiliation/preference instead of legal reasoning) are continuously shocked that lawyers and law professors defend the integrity of the judiciary, even in the face of contrary empirical evidence. See JEFFrEY A. SEGAL AND HAROLD J. SPAETH, THE SuPREME COURT AND THE ATTITUDINAL MODEL (1993)

64 Stephen N. Subrin, How Equity Conquered Common Law: The Federal Rules of Civil Procedure in Historical Perspective, 135 U. PA. L. REV. 909 (1987). Of course, in American law simplification revolutions are often short-lived. Christopher Fairman and others have persuasively argued that notice pleading (the main simplification effort of the Federal Rules of civil Procedure) is currently dead for all practical purposes. Christopher M. Fairman, The Myth of Notice Pleading, 45 ARIZ. L. REV. 987 (2003).
} 
In my third year of law school I was fortunate enough to be selected for a clerkship on the United States Court of Appeal for the Fourth Circuit. When I received the clerkship one of my professors advised "Take our Federal Courts course in the Spring. It's the hardest class in law school, but you'll need it for the clerkship." I asked around the law school and this was indeed the scuttlebutt - everyone who had a clerkship was going to take the class, and it was extremely difficult material. The Federal Courts course thus embodied my complexity theory. It was filled with future "elite" lawyers (those who had federal clerkships) and involved the study of some of the most complex and complicated law in America.

The Federal Courts course covers the role of the federal courts in the federal system, with a particular focus "on standing and other justiciability questions; power of Congress to define the scope of federal court jurisdiction; state sovereign immunity; abstention; interjurisdictional preclusion and injunctions; and appellate and collateral review, including habeas corpus." ${ }^{.65}$

The course was as advertised, and the cases were quite difficult to digest. Nonetheless, I found I had quite a different reaction to the material than my classmates and the professor, who seemed enthralled by the onion-like layers of complexity. It struck me as odd that a set of cases drafted by the finest judges in the land (U.S. Supreme Court Justices) based on law almost wholly within the Justice's control (i.e. constitutional or federal common law) would be so convoluted and complicated. I had a true

\footnotetext{
${ }^{65}$ This quote comes from the Vanderbilt Law School catalogue. Vanderbilt University Law School, LAW 744: Federal Courts and the Federal System, http://law.vanderbilt.edu/academics/curriculum/index.aspx (follow "Upper Level Elective Courses" hyperlink; then follow "Federal Courts and the Federal System" hyperlink). (see http://law.vanderbilt.edu/academics/curriculum/elective-courses/federal-courts-and-thefederal-system/index.aspx). This course description is consistent with that of other elite law schools. Stanford Law School, Federal Courts, http://www.law.stanford.edu/program/courses/ (follow "2nd/3rd Year Program" hyperlink; then follow "Federal Courts" hyperlink under "Civil Procedure and Litigation" heading). (See, e.g., http://www.law.stanford.edu/program/courses/details/283/Federal\%20Courts/)
} 
"emperor's new clothes" moment that semester, as I came to realize that smart people working on hard problems do not always reach simple, or even good, solutions. Often smart people working on hard problems produce a vast quantity of unnecessary complexity.

The law of standing was one of the prime offenders in Federal Courts, and as such it helps elucidate both the crass and subtle explanations for legal complexity. Standing governs when an individual may sue in court. Article III of the U.S. Constitution limits the federal judicial power to hearing "cases" or "controversies." The Court has used these terms to limit the types of cases federal courts may hear. Standing - along with ripeness, mootness, and the political question doctrine - help define when a plaintiff may bring suit in Federal Court. ${ }^{66}$

The Supreme Court has announced "three requirements that constitute the irreducible constitutional minimum of standing. First, a plaintiff must demonstrate an injury in fact, which is concrete, distinct and palpable, and actual or imminent. Second, a plaintiff must establish a causal connection between the injury and the conduct complained of-the injury has to be fairly traceable to the challenged action of the defendant, and not the result of some third party not before the court. Third, a plaintiff must show the substantial likelihood that the requested relief will remedy the alleged injury in fact." ${ }^{67}$

In addition to the constitutional requirements there are a series of prudential standing principles: "The general prohibition on a litigant's raising another person's legal

\footnotetext{
66 Ripeness asks whether the case is ready to be tried. Mootness asks whether the plaintiff still has an interest in the case at issue. The political question doctrine asks whether the case raises issues of an essentially political and non-judicial nature.

${ }^{67}$ McConnell v. Fed. Election Comm'n, 540 U.S. 93, 225-26 (2003) (internal citations, brackets, and quotation marks omitted).
} 
rights, the rule barring adjudication of generalized grievances more appropriately addressed in the representative branches, and the requirement that a plaintiff's complaint fall within the zone of interests protected by the law invoked." ${ }^{68}$ In many of the standing cases the Court does not differentiate between whether the question was prudential or constitutional. ${ }^{69}$ Because prudential standing can be over-ridden by Congress but Constitutional standing cannot the distinction is, nevertheless, quite important. ${ }^{70}$

Each of the six tests listed above have sub-tests, and some have competing tests that are used in some cases but not others. Take the very first of the three constitutional prongs - injury. Erwin Chemerinsky separates the "injury-in-fact" requirement into two related questions - did the plaintiff personally suffer the injury and was the injury sufficiently concrete. ${ }^{71}$

Even this division does not capture the multi-faceted nature of the "injury-in-fact" determination, because it all tends to bleed together. For example, in Lujan v. National Wildlife Federation $^{72}$ the plaintiff, National Wildlife Foundation, lost because no individual member of the organization alleged that she had traveled to the specific land at issue. Justice Scalia wrote Lujan, and in addition to the narrow holding requiring a visit to the affected land, he stated a quite firm requirement that environmental plaintiffs state a "concrete and particularized" injury and set forth "specific facts" to support their

\footnotetext{
${ }^{68}$ Allen v. Wright, 468 U.S. 737, 751 (1984) (internal citations, brackets, and quotation marks omitted). Erwin Chemerinsky offers a slightly more readable definition of the prudential requirements: "First, a party generally may assert his or her own rights and cannot raise the claims of third parties not before the court. Second, a plaintiff may not sue as a taxpayer who shares a grievance in common with all other taxpayers. . . . Third, a party must raise a claim within the zone of interests protected by the statute in question." Erwin Chemerinsky, Federal Jurisdiction 58 (2d. ed. 1994).

${ }^{69}$ Craig R. Gottlieb, How Standing Has Fallen: The Need to Separate Constitutional and Prudential Concerns, 142 U. PA. L. REV. 1063 (1994).

${ }^{70}$ Chemerinsky, supra note 60 , at 57-58.

${ }^{71} \mathrm{Id}$. at 58-65.

72497 U.S. 871 (1990).
} 
claims, not just generalized harm from environmental degradation. ${ }^{73}$ Thus Lujan had both a "personal" injury aspect (did the plaintiff personally visit the affected land) and a "concreteness" aspect (was the alleged injury concrete and particularized enough).

The concreteness portion of Lujan, however, was later over-ruled, or substantially watered down, by Friends of the Earth, Inc. v. Laidlaw Envtl. Servs. ${ }^{74}$ Friends of the Earth found standing where a plaintiff alleged visiting the actual polluted river at issue, but could not allege an injury concrete enough to satisfy Justice Scalia, who wrote a scathing dissent. ${ }^{75}$ As such, Friends of the Earth upheld the "personal" aspect of Lujan, but allowed a lesser showing on the concreteness question, all without explicitly overruling anything that came before.

The funny thing about this very, very brief description of one small corner of standing law is that even this black-letter and bare bones description of the law is bewildering, and I have made almost no effort whatsoever to describe or synthesize the cases themselves. I have not, because standing cases have been called "notoriously inconsistent,"76 a "jumbled mess,"77 “a quagmire,"78 a "chaotic collection of rules and standards,"79 “confused,"

\footnotetext{
${ }^{73} I d$. at $560-65$.

74528 U.S. 167 (2000).

${ }^{75} \mathrm{Id}$. at $198-215$.

${ }^{76}$ Hein v. Freedom From Religion Foundation, Inc., 127 S.Ct. 2553, 2574 (2007) (Scalia, J., concurring).

77 John A. Ferejohn \& Larry D. Kramer, Independent Judges, Dependent Judiciary: Institutionalizing Judicial Restraint, 77 N.Y.U. L. REV. 962, 1010 (2002).

${ }^{78}$ Kathleen C. Engel, Do Cities Have Standing? Redressing the Externalities of Predatory Lending, 38 CONN. L. REV. 355, 389 (2006).

79 Nancy Staudt, Modeling Standing, 79 N.Y.U. L. REV. 612, 671 (2004).

${ }^{80}$ Michael A. Cohen, Plaintiffs' Standing in Lee v. Oregon: The Judicially Assisted Demise of the Oregon Death with Dignity Act, 74 OR. L. REV. 741, 743 (1995).

81 Andrew F. Hessick, Standing, Injury in Fact, and Private Rights, 93 CORNELL L. REV. 275, 276 (2008).
} 
of all law reviews for the term "standing" in the same sentence as "complex" or “complexity" results in 1299 documents. ${ }^{82}$

There are several reasons why standing law is a great case study for the complexity theory laid out above. First, while standing may be virtually unknown outside of the legal profession, it is critically important to litigants. If a person is willing to suffer the expense and hassle of bringing a lawsuit in Federal Court, it is of tremendous importance that they not get bounced from court for lack of standing. ${ }^{83}$ Standing is also an invaluable tool for federal courts, because it is one of the main ways for courts to get rid of cases they do not like short of a decision on the merits.

Second, standing, ripeness, mootness, and the political question doctrine are all fully within the control of the Supreme Court, and to a lesser extent the lower federal courts. None of the complexity in this law comes from Congressional actions, or bad legislative drafting, or overweening bureaucratic enthusiasm. Standing is a purely judicial doctrine, created as a gloss on two words (case and controversy). This means that the judges involved have no one to blame but themselves for complexity and indeterminacy.

Third, standing is one of those areas of the law where it is obvious that the complexity involved is not the kind that leads to clearer application of the law on a more individual basis, i.e. standing complexity is not of the sort that might confer a benefit along with its costs. To the contrary, as standing law has grown more complicated its

\footnotetext{
${ }^{82}$ I searched for "standing /s complex complexity" in the JLR database.

${ }^{83}$ The expense and hassle of litigation are one of the most persuasive arguments against standing doctrine: if the Court is really worried about entertaining litigation where the litigants who do not truly care about their "case" or "controversy," the willingness to litigate alone should be strong evidence.
} 
application has grown increasingly cumbersome and its applicability to any given set of facts has grown even harder to predict.

As noted above, this makes standing a valuable area of the law for lawyers. For any given Federal environmental or group rights case there is the strong possibility of a challenge to standing. Because of the confusion in the law this challenge will require a substantial amount of legal work for all the litigants, and it will allow clever lawyers to craft and re-craft highly technical arguments on either side of the issue.

Fourth, standing law well establishes the value of complexity for judges. As noted above, standing and related doctrines are an easy route for judges to get rid of cases they do not like, either because of political preferences or a distaste for the litigants or the subject area. Richard Pierce argues that lawyers can predict standing decisions "with much greater accuracy if they ignore doctrine and rely entirely on a simple description of the law of standing that is rooted in political science: judges provide access to the courts to individuals who seek to further the political and ideological agendas of judges." ${ }^{84}$ Standing is the perfect case for the complexity theory because the law is sufficiently complex that a judge has great discretion to decide whether or not to find standing, and yet still has plenty of complexity to cover her hindquarters in a learned written opinion or order.

\footnotetext{
${ }^{84}$ Richard J. Pierce, Is Standing Law or Politics?, 77 N.C. L. ReV. 1741, 1742-43 (1999). Pierce establishes this argument as follows: "Five Supreme Court decisions issued between 1991 and 1998 illustrate the accuracy of the political scientist's description of the law of standing. In those cases, the Court resolved standing disputes applicable to environmentalists (two cases), employees, prisoners, and banks. In each case, the Justices divided either five-to-four or six-to-three on the standing issue. In each case, the "votes" of the Justices were as easy to predict as the votes of their ideological counterparts in the legislature. Liberals voted to grant access to the courts to environmentalists, employees, and prisoners, but not to banks. Conservatives voted to grant access to banks, but not to environmentalists, employees, or prisoners. Of course, in each case, all the Justices claimed to reach their politically preferred result through objective application of legal doctrines. The applicable doctrines are so malleable, however, that it is impossible to avoid the inference that the Justices manipulated the doctrines to rationalize their politically preferred results." Id. at 1743 .
} 
Fifth, standing also shows how judges are drawn to, and enjoy, complexity. The Supreme Court has returned again and again to standing in the last thirty years, with each new foray seemingly further muddying the waters. The cases are often split, and they frequently involve lengthy dissents and multiple concurrences. In short, there is little to suggest that the Justices dislike standing law, or that they see any particular need to clarify, avoid, or scrap it. To the contrary, the standing cases look to be the work of legal technicians and theorists who are enjoying themselves.

In short, the law of standing fits both the public choice and institutional analyses of the judicial bias towards complexity. It also perfectly fits the predictive portion of this paper: it involves an area where judges want flexibility to decide cases based on their own preferences, an area (generally constitutional cases or group challenges to federal action or statutes) that draws elite lawyers, and it's an area of interest for the judges.

\section{Conclusion}

At this point I hope I have convinced you that a combination of institutional and public choice factors lead both lawyers and law-making judges to favor complexity in law creation. The question of what, if anything, can or should be done about the problem, however, is harder to tackle. One hope is that judges will recognize the costs of complexity and adjust their behavior accordingly. Given the judicial taste for multifactor balancing tests and complicated procedures this result seems rather unlikely. There is an old adage that hard cases make bad law. A corollary might be that interesting cases make unnecessarily complex law.

The problem is that any more fundamental changes require a radical reworking of the American Justice System. Adrian Vermeule has argued that at least some Supreme 
Court Justices should be non-lawyers. ${ }^{85}$ In order to avoid complexity, however, it would seem necessary to either retrain lawyers before becoming judges, separately train judges, or select judges from among both lawyers and non-lawyers. It would of course be necessary to consider the other costs and benefits of any such move. Institutional change should never be advocated in a vacuum, as we are always choosing between several suboptimal options. ${ }^{86}$ Nevertheless, there is reason to believe that the very structure of the legal and judicial professions may be contributing to our case of "hyperlexis," which Bayless Manning defined as America's "national disease - the pathological condition caused by an overactive law-making gland." ${ }^{, 87}$

\footnotetext{
${ }^{85}$ Adrian Vermeule, Should We Have Lay Justices?, 59 STAN. L. REV. 1569 (2007).

${ }^{86}$ NeIL K. KOMESAR, IMPERFECT ALTERnATIVES: CHOOSING INSTITUTIONS IN LAW, ECONOMICS, AND Public Policy (University of Chicago Press 1994).

${ }^{87}$ Bayless Manning, Hyperlexis: Our National Disease, 71 Nw. U. L. REV. 767, 767 (1977).
} 